\title{
Pathways to ensure universal and affordable access to hepatitis $C$ treatment
}

\author{
Caitlin H. Douglass', Alisa Pedrana', Jeffrey V. Lazarus' ${ }^{2,3}$, Ellen F. M. 't Hoen ${ }^{4,5}$, Radi Hammad'6, \\ Ricardo Baptista Leite ${ }^{7,8}$, Andrew Hill ${ }^{9}$ and Margaret Hellard $1,10,11,12^{*}$
}

\begin{abstract}
Direct-acting antivirals (DAAs) have dramatically changed the landscape of hepatitis C treatment and prevention. The World Health Organization has called for the elimination of hepatitis $C$ as a public health threat by 2030. However, the discrepancy in DAA prices across low-, middle- and high-income countries is considerable, ranging from less than US\$ 100 to approximately US\$ 40,000 per course, thus representing a major barrier for the scale-up of treatment and elimination. This article describes DAA pricing and pathways to accessing affordable treatment, providing case studies from Australia, Egypt and Portugal. Pathways to accessing DAAs include developing comprehensive viral hepatitis plans to facilitate price negotiations, voluntary and compulsory licenses, patent opposition, joint procurement, and personal importation schemes. While multiple factors influence the price of DAAs, a key driver is a country's capacity and willingness to negotiate with pharmaceutical companies. If negotiations do not lead to a reasonable price, governments have the option to utilise flexibilities outlined in the Agreement on TradeRelated Aspects of Intellectual Property Rights. Affordable access to DAAs is underpinned by collaboration between government, civil society, global organisations and pharmaceutical companies to ensure that all patients can access treatment. Promoting these pathways is critical for influencing policy, improving access to affordable DAAs and achieving hepatitis C elimination.
\end{abstract}

Keywords: Healthcare financing, Hepatitis C, Treatment

\section{Background}

An estimated 67 million people live with chronic hepatitis C infection worldwide [1]. Chronic hepatitis C causes cirrhosis, liver cancer and approximately 399,000 deaths annually [2]. Globally, people who inject drugs (PWID) have the highest hepatitis $C$ prevalence (42-62\%) [3]. In 2016, the World Health Organization (WHO) set targets for eliminating hepatitis $\mathrm{C}$ as a public health threat, calling for an $80 \%$ reduction in incidence and a $65 \%$ reduction in related deaths by 2030 [4]. WHO estimates that approximately 1.5 million new hepatitis $\mathrm{C}$ infections occur annually [1], yet, in 2017, only 1.6 million patients were treated for hepatitis $\mathrm{C}$ and fewer than 1.5 million are expected to be treated in 2018 [1]. If current trajectories of new infections and treatment uptake continue, hepatitis $\mathrm{C}$ will

* Correspondence: margaret.hellard@burnet.edu.au

${ }^{1}$ Burnet Institute, Melbourne, Australia

${ }^{10}$ Department of Infectious Diseases, The Alfred Hospital, Melbourne,

Australia

Full list of author information is available at the end of the article certainly not be eliminated by 2030 and only 12 countries are likely to achieve elimination [1]. Therefore, a multi-pronged approach that includes the scale-up of affordable treatment is essential to achieve elimination [5-7].

The advent of direct-acting antivirals (DAAs) in 2013 led to optimism that hepatitis $\mathrm{C}$ elimination is achievable [8]. DAAs have a cure rate of over $95 \%$, treatment duration of only 8-12 weeks, and fewer and less severe side-effects than their predecessors [2]. However, in many countries, DAA prices discourage treatment, impeding progress towards elimination $[9,10]$, and whilst DAA prices have declined, they vary considerably - from less than US\$100 per treatment course to approximately US\$ 40,000 $[9,11$, 12]. This paper describes current pricing of DAAs and highlights the pathways and mechanisms for governments and civil society to access affordable treatment.

\section{Drug development}

The advancing of drugs through research and development $(R \& D)$ is a long-term process, with an only $12 \%$ 
probability of a drug gaining marketing approval [13]. Estimates of the average R\&D cost vary from US\$ 161 million [14] to US\$ 2.6 billion per drug, including approved and unsuccessful compounds and opportunity costs [13]. Additional costs post-approval include surveillance, manufacturing, distribution and marketing.

\section{Marketing authorisation}

Following clinical trials, drug companies must obtain marketing authorisation to sell their products (e.g. through the Food and Drug Administration (FDA) or European Medicines Agency). Over 2011-2015, the FDA and European Medicines Agency median approval times for new therapeutic agents were 306 and 383 days, respectively [15]. Accelerated review processes apply for important medicines that treat serious conditions and fill an unmet need or demonstrate substantial improvements over existing treatments [16]. For example, the FDA granted sofosbuvir, a highly effective DAA manufactured by Gilead Sciences, a priority review [17], and it was approved for the treatment of chronic hepatitis $\mathrm{C}$ within 242 days of application [18].

\section{DAA pricing}

Upon marketing approval, decisions on pricing and reimbursement are required. These decisions vary according to whether governments negotiate discounts or whether pharmaceutical companies set prices [19]. In 2013, the price of sofosbuvir ranged from US\$ 900 in Egypt to US\$ 95,000 in the US $[11,12,20]$. Since then, other DAAs have been released and generic DAAs have begun to generate competition, leading to discounted prices [9]. Additionally, manufacturing costs have also fallen, with the costs of a 12-week course of sofosbuvir estimated at US\$ 47 [21].

DAAs contribute significantly to pharmaceutical company profits. In 2017, Gilead reported US\$ 26.1 billion in sales, including US\$ 9.1 billion from DAAs [22]. In 2017, Bristol-Myers Squibb's product revenue totalled US\$ 20.8 billion, including US\$ 406 million from hepatitis C products [23]. Whilst the exact costs of DAA R\&D, manufacturing and distribution are unknown, sales data suggest that pharmaceutical companies make significant profits from DAAs, particularly from high-income countries.

The initial price of DAAs was particularly daunting as it required governments to dedicate large proportions of their health budget to hepatitis $C$ treatment [24]. However, despite DAA manufacturing costs falling, prices still vary, remaining stubbornly high in certain countries [11]. A number of high-income countries, including Australia, Finland, France, Iceland, Italy, Norway, Portugal, Scotland, Spain and Sweden, have negotiated price agreements that allow most patients to access DAAs, enabling a broad public health response rather than a disease-staged approach [12]. In 2015, Georgia, a middle-income country, established the world's first hepatitis C elimination demonstration project, with Gilead Sciences providing free treatment for all patients [25]. Georgia's elimination plan derived from strong political commitment, public support and health system capacity [26].

Other countries (e.g. US [10], Denmark and Poland [12]) are paying higher prices for DAAs, necessitating treatment restrictions based on fibrosis stage and substance use [27, 28]. A review showed that, of 35 European countries and jurisdictions, $46 \%$ restricted treatment to patients with fibrosis at stage F2 or higher and 17\% required abstinence from illicit substances [28]. Importantly, these restrictions were not based on treatment effectiveness, with DAAs achieving $>95 \%$ cure rates in patients without cirrhosis or with compensated cirrhosis, PWID and those who consume alcohol [29-32] and 78-87\% cure rates for patients with compensated cirrhosis [33]. Additionally, the key to preventing new infections is stopping viral transmission. Mathematical modelling demonstrates that PWID with hepatitis $\mathrm{C}$ must be treated to reduce incidence and reach WHO elimination targets $[34,35]$. Hence, treatment restrictions for PWID and other priority groups must be lifted.

\section{Pathways to accessing DAAs}

Whilst DAA price reductions in some countries facilitate greater treatment access, prices need to be affordable worldwide. A government's capacity to negotiate with pharmaceutical companies is a key driver of drug prices. Other pathways to accessing affordable DAAs include voluntary and compulsory licensing, patent opposition, personal importation schemes, and joint procurement (Fig. 1).

\section{Centralised price negotiations}

In the US, some patients are eligible for DAAs through Medicare (federal health insurance for people who are older or disabled) and Medicaid (government-subsidised healthcare programmes for people with low income) [36]. While Medicare cannot negotiate drug prices directly [9], Medicaid has previously obtained manufacturer rebates for HIV drugs above the required Medicaid price discounts for all drugs. The Veterans Health Administration can negotiate deals for veterans and private insurance companies can negotiate for clients [37]. However, strict confidentiality agreements between payers and manufacturers prevent price transparency [36]. Consequently, US patients pay substantially more for DAAs than citizens of other high-income countries, thus reducing treatment access [9]. US states and insurance companies vary considerably regarding DAA restrictions and reimbursement based on fibrosis stage, substance use, co-infection with HIV and prescriber type [38]. However, several states have relaxed their DAA criteria, allowing increased treatment utilisation [39]. 


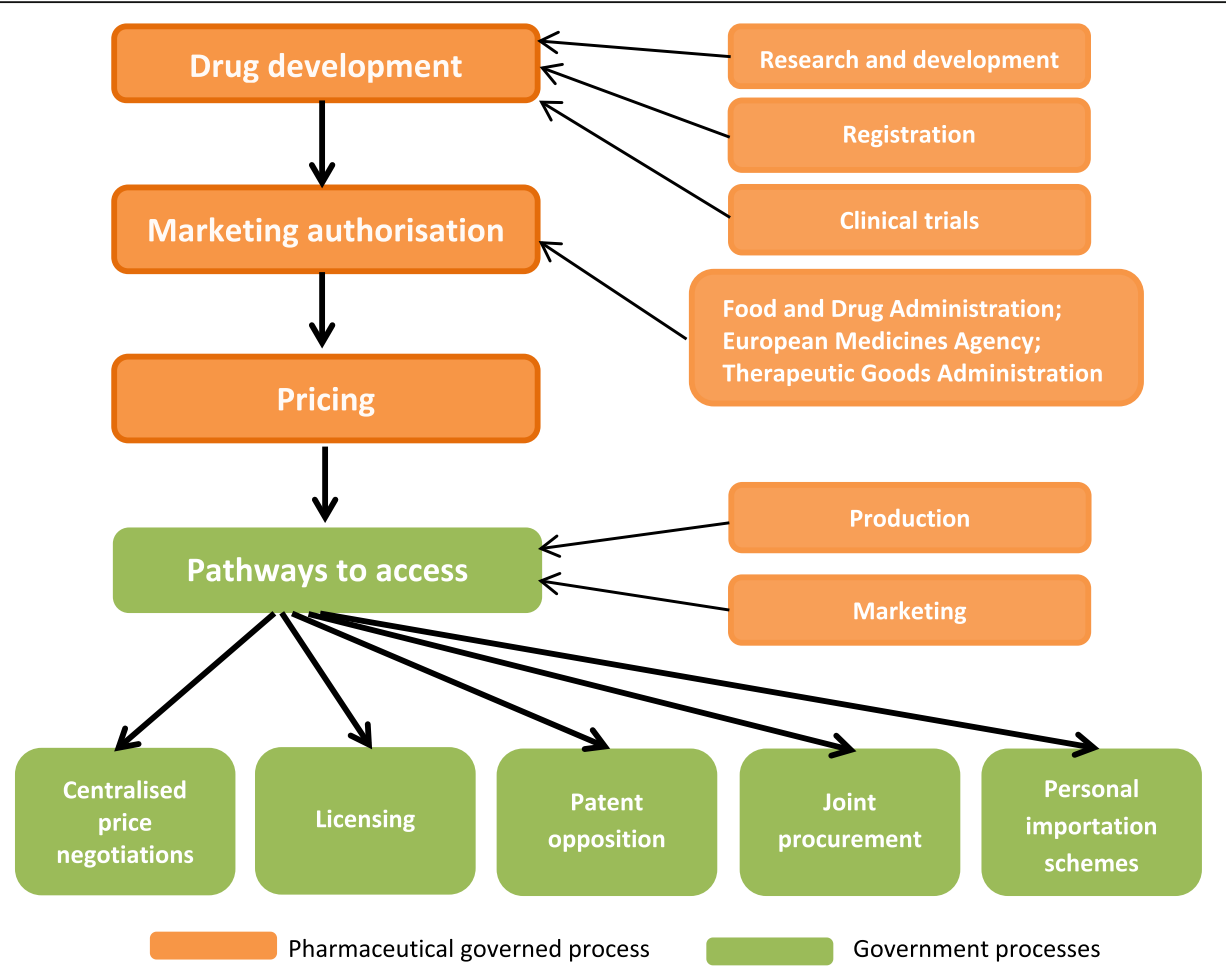

Fig. 1 Pathways to accessing direct-acting antivirals

Despite restrictions on drug price negotiation in the US, legislation (under 28 U.S.C. \$1498) permits the government to purchase generic medications at less than $1 \%$ of their branded list price plus a reasonable royalty [37]. During the 2001 anthrax outbreak, the US Government threatened to use this legal provision, leading to swift negotiations with the manufacturer for reduced medication costs [37]. This mechanism could be used to reduce DAA prices.

In other countries, governments can negotiate a reasonable price for pharmaceuticals with patent holders [40]. Australia and Portugal have negotiated volume-based agreements with pharmaceutical companies (case studies 1 and 2), and Italy and Spain have negotiated DAA course prices of less than $€ 8000$. It is apparent that pharmaceutical companies are willing to negotiate reasonable prices when governments present plans that ensure a greater number of patients undertake treatment.

\section{Intellectual property law}

In 1994, the World Trade Organization (WTO) established the Agreement on Trade-Related Aspects of Intellectual Property Rights (TRIPS) [40]. The TRIPS Agreement sets global minimum requirements for creating and protecting intellectual property. WTO members, excluding those regarded as least developed countries (LDCs) (low-income countries at high risk of economic and environmental shocks), must provide patent protection for inventions for at least 20 years [41]. Although patents provide an incentive to innovate, they can also create monopolies, reduce competition and increase prices [42]. Patent holders can prevent generic versions of patented medicines from being produced or made available. However, LDCs are not obliged to provide or enforce medicine patents or data protection until at least 2033, allowing the legal production and marketing of generic medicines in these countries [43].

The basic compound patent for sofosbuvir expires in a number of patent-granting countries in 2025 [44]. Upon patent expiry, generics can be freely produced and disseminated, creating competition and reducing costs for governments and consumers [45, 46]. For example, generic competition for HIV antiretroviral therapy (ART) contributed to a 99\% price reduction [47]. The TRIPS Agreement also enables governments to prevent a patent's monopoly effects and access generics prior to patent expiry (Fig. 2) [41]. In 2001, the WTO adopted the Doha Declaration on TRIPS and Public Health, clarifying that TRIPS should not hamper governments' ability to protect public health and listing flexibilities enabling widespread access to medicines [48].

Compulsory licenses and public non-commercial use licenses Examples of TRIPS flexibilities that WTO member states can use to pursue public health goals include granting compulsory licenses to third parties without patent holder consent and public non-commercial or government use of patents $[41,44]$. These licenses allow local production or importation of generics [20]. Importantly, TRIPS does not 


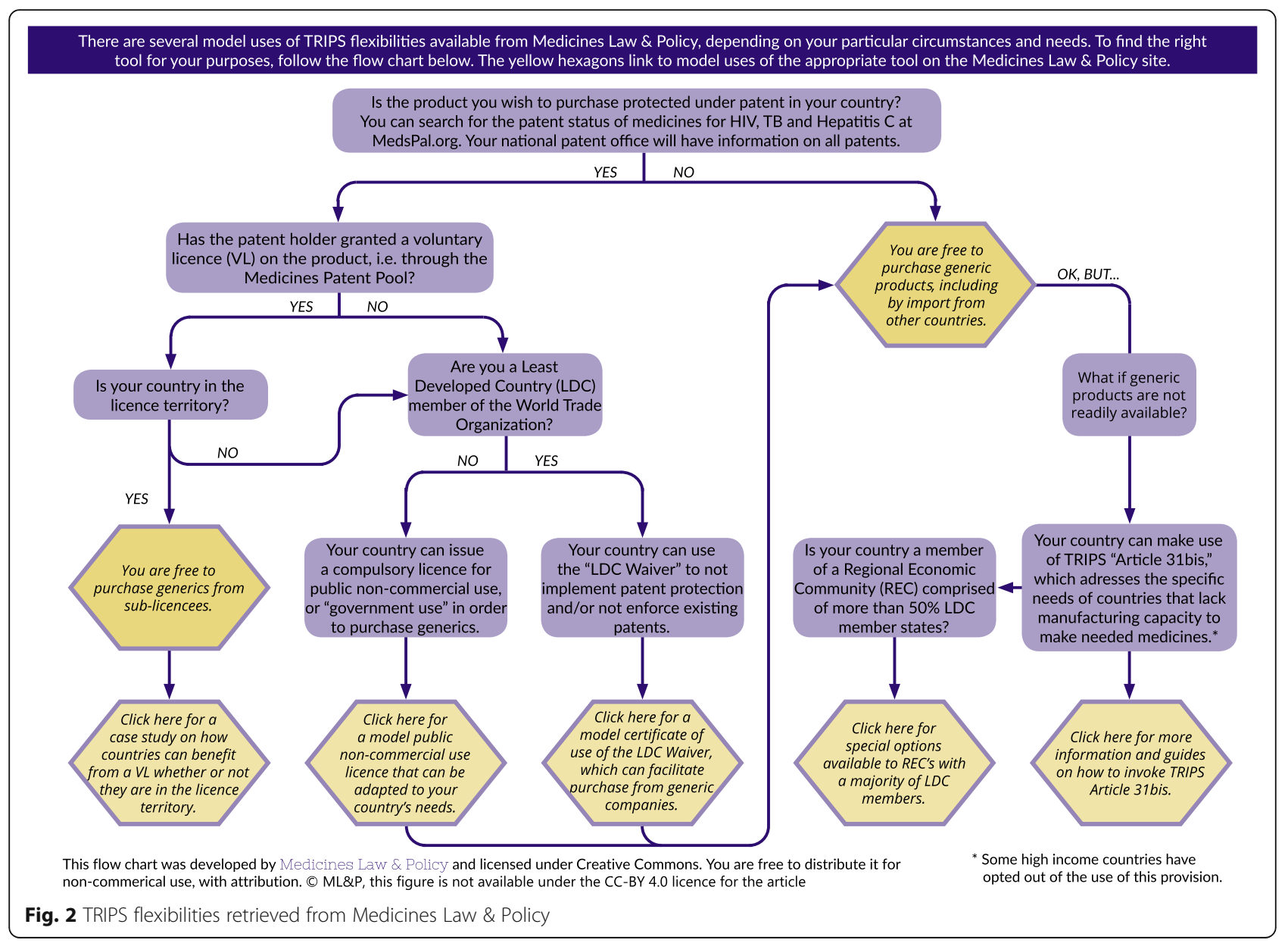

require prior negotiations for a voluntary license in emergency or urgent situations [41]. In January 2017, WTO amended TRIPS with article 31(bis) to provide a special compulsory license to supply medicines to countries without sufficient production capacity [49]. Article 31(bis) allows Regional Economic Communities, consisting mostly of LDCs (all African), to bundle demand to supply the entire region, regardless of whether a developing country or an LDC will benefit.

Compulsory licensing (particularly non-commercial use licenses) facilitated procurement of generic ART for HIV when voluntary licenses were unavailable [50]. However, middle- and high-income countries that use compulsory licensing for DAAs are likely to experience significant opposition from manufacturers defending their monopoly and from countries where multinational pharmaceutical companies operate and manufacture [51]. To date, only Malaysia has issued a compulsory license for a DAA (late 2017) [44].

\section{Voluntary licenses}

Pharmaceutical companies can establish agreements with generic manufacturers allowing the manufacture and sale of lower-priced generics before patent expiry [44, 52]. In 2010, the Medicines Patent Pool (MPP) was established to negotiate voluntary licenses with patent holders to supply ART in low- and middle-income countries [53]. MPP licenses will save the global health community an estimated US\$ 2.3 billion for HIV treatment over 2010-2028 [53].

The MPP's remit recently expanded to include DAAs, listing daclatasvir (GSK) in 2016. Prior to this expansion, Gilead established voluntary licensing agreements with 11 Indian companies, enabling them to manufacture and market bioequivalent DAAs in 101 low-income countries. Generic manufacturers with a voluntary license set their own price and pay royalties to Gilead [54]. These agreements excluded Brazil, China, Morocco and Thailand, middle-income countries with high hepatitis $\mathrm{C}$ burdens [55, 56]. However, countries can issue a compulsory license and produce or purchase generic medications, including from sub-licensees [51]. Interestingly, when Malaysia issued a compulsory license for sofosbuvir, Gilead responded by including Malaysia, Thailand, Ukraine and Belarus in their license agreement territory, showing the direct and indirect power of compulsory licensing [57]. 
Gilead Sciences has provided voluntary licenses for both ARTs and DAAs. Bristol-Myers Squibb has licensed daclatasvir to MPP for sale in 112 countries [58].

\section{Patent opposition}

Pharmaceutical companies can be prevented from securing a monopoly using patent opposition [59]. In 2015, Médecins du Monde and civil society organisations from 17 countries challenged Gilead's sofosbuvir patent, leading to amendment of the patent claims [60] and availability of generic versions of sofosbuvir in Europe in 2024 rather than 2028 [61]. Civil society organisations launched similar oppositions in Argentina, Brazil, China, Colombia, India, Ukraine and the US [61]. In 2012, Médecins Sans Frontières established a patent opposition database to disseminate information on claims and oppositions [62], an important tool for transparency and collaboration between public health groups and legal and technical experts on pharmaceutical patent challenges.

\section{Joint procurement}

Governments can obtain lower pharmaceutical prices by allowing a subset of payers to negotiate prices as one entity [44, 63]. Benefits of joint procurement include allowing authorities to negotiate volume-based discounts, reap administrative savings and pool skillsets [44, 64]. Joint procurement can occur through collaborative agreements between contracting authorities or through permanent joint procurement organisations [64]. In 2015, Mercosur (a trade block involving Argentina, Brazil, Paraguay, Uruguay and Venezuela) and associated countries (Chile, Colombia, Peru and Ecuador) completed the first joint procurement of DAAs with support from the Pan American Health Organization Strategic Fund [65], securing the lowest price in the region (US\$2292 per treatment) [66].

In 2017, the Centre for Disease Analysis Foundation established the Global Procurement Fund (GPRO) to support expanded access to affordable and quality treatments in low- and middle-income countries [67]. GPRO uses pooled purchasing to negotiate prices for large volumes of DAAs, with 104 countries currently accessing sofosbuvir through this mechanism [68]. Drugs supplied by GPRO must meet quality standards from $\mathrm{WHO}$, a stringent regulatory authority or an independent expert review panel [67]. In 2008, the European Commission released a fact sheet to aid organisations to establish joint procurement [64]; however, this is yet to be employed for DAAs. Effective procurement of DAAs requires reliable surveillance and modelling data to predict the number of patients who need treatment [44].

\section{Personal importation schemes}

In various countries (e.g. Australia [69], Italy [70] and Switzerland [71]), patients are legally entitled to import
1-3 months of personal medication. Patients living in countries without subsidised access to treatment can purchase generic DAAs through online buyers' clubs [52]. The Australian-based FixHepC Buyers Club allows patients with a prescription to import a 12-week course of generic sofosbuvir and daclatasvir for US\$ 1000 [72]. Cure rates of generic DAAs imported into Australia are similar to branded treatments [73]. However, in some countries, physicians cannot prescribe unlicensed medications [56]. Indeed, personal importation is not a long-term solution, with treatment uptake being somewhat ad hoc rather than part of a cohesive public health response.

\section{Case study 1: Australia}

In Australia, the Therapeutic Goods Administration (TGA) regulates the pharmaceutical sector [74] and the Pharmaceutical Benefits Scheme (PBS) subsidises listed medications for Australian residents [75]. General and concession patients make co-payments of AU\$ 39.50 and AU\$ 6.40 per script, respectively [76]. If a TGA-approved drug is not listed on the PBS, Australians can still access these medications, although generally at full price. Pharmaceutical companies can apply for PBS listing through the Pharmaceutical Benefits Advisory Committee (PBAC) [75]. If the PBAC recommends the drug, the Department of Health negotiates a subsidised price with the pharmaceutical company [75].

In 2014, the TGA approved sofosbuvir for the wholesale cost of AU\$ 110,000 per course. After long price negotiations between the government and pharmaceutical companies, PBAC recommended DAAs for PBS listing on March 1, 2016. The Australian government budgeted approximately AU\$ 1.2 billion over 5 years to treat hepatitis C [56], following a volume-based, risk-sharing deal with pharmaceutical companies [56]. Treatment costs are capped at approximately AU\$ 250 million annually, regardless of the number of people treated [77], yet the 'base price' the government pays per treatment is thought to be approximately AU\$ 12,000-15,000. However, if annual treatment costs exceed the annual cap, these are covered by the pharmaceutical companies; therefore, the more patients treated, the lower the cost per course, which incentivises treatment scale-up. Between March 2016 and June 2017, approximately 43,360 patients (19\% of all Australian patients with hepatitis C) were treated [78] at an estimated cost of less than US\$ 8000 per course, one of the lowest prices per patient in high-income countries.

Importantly, prescribing guidelines allow treatment by specialists, general practitioners and nurse practitioners, facilitating uptake of treatment outside hospital settings [79]. Further, fibrosis and substance use do not affect eligibility [79]. Based on PBS co-payment schemes, general patients pay out-of-pocket AU\$ 120 and concession patients pay AU\$ 20 per treatment course [76], making 
the DAA price for individual patients one of the lowest globally.

\section{Case study 2: Portugal}

Initially, in Portugal, DAAs cost approximately $€ 40,000$ per patient [12] and treatment was restricted to patients with severe cirrhosis who required a liver transplant, which led to community advocacy in the media and parliament [80] designed to shift discussions about hepatitis $\mathrm{C}$ from prevention to cure [80]. In February 2015, the Portuguese government announced a risk-sharing and volume-based agreement with Gilead, enabling universal access to treatment for all patients, regardless of fibrosis stage [80, 81]. Gilead would initially only receive payment per patient (less than $€ 7000)$ if treatment led to a cure. A national registry was established to monitor cure rates 12 weeks post-treatment [81]. As of July 2017, 17,591 patients had been authorised treatment, 11,972 patients had initiated treatment and 6639 (96.5\%) patients were clinically cured [82]. The programme has averted 3477 premature liver deaths, 339 liver transplants and 5417 cases of cirrhosis [83], and saved the government over $€ 271$ million on treatment of hepatitis $\mathrm{C}$ complications [83]. A national plan to improve care is currently under development [84].

\section{Case study 3: Egypt}

Egypt has the highest hepatitis $\mathrm{C}$ prevalence worldwide [85], mostly attributable to transmission through injections to treat schistosomiasis between the 1950s and 1980s [85]. In 2008, an estimated 9.8\% of Egypt's population aged 1559 years was hepatitis $C$ positive; prevalence was highest among those aged 50-59 [86]. In 2015, the estimated prevalence among those aged 15-59 years declined to $7.0 \%$ [87], predominantly due to ageing of the population with hepatitis C [88, 89].

In 2006, the National Committee for Control of Viral Hepatitis was established to measure hepatitis $\mathrm{C}$ burden and prepare a national treatment programme [90] and, in 2014, a national plan for prevention, control and treatment of viral hepatitis was released. The National Committee for Control of Viral Hepatitis and the Health Insurance Organization set up 189 government treatment facilities and created a national online database to register patients [91]. Importantly, the Egyptian government rejected patent applications for sofosbuvir, enabling local production and supply of generics [92]. In 2014, Egypt had a limited supply of branded sofosbuvir, which cost US\$ 900 for a 12-week treatment course still expensive relative to Egypt's financial resources [91]. Treatment was restricted to patients with advanced fibrosis, hepatitis B or HIV co-infection, and post-liver transplants, leading to long waiting lists [91]. Subsequently, negotiations and generic production reduced prices significantly and DAAs became available to all patients [91]. Between October 2014 and December 2017, 1.4 million patients commenced treatment, with cure rates above $90 \%$ [91]. Because there are no compound patents on sofosbuvir and daclatasvir in Egypt [93], treatment is now available for US\$ 84 per treatment course from generic manufacturers [21]. In 2016, the Ministry of Health established the Viral Hepatitis Control Administration, aiming to reduce new infections, screen 10 million people, eliminate waiting lists and enhance their sentinel surveillance systems [94]. Despite high hepatitis $\mathrm{C}$ prevalence, Egypt is on track to achieve WHO elimination targets [1].

\section{Ways forward and future challenges}

To achieve the WHO 2030 elimination targets, DAA prices, including those governments or insurers pay per course and for individual patients, must generally fall to ensure universal access [95]. Governments need to negotiate drug prices and be prepared to use the TRIPS flexibilities to ensure satisfactory results. In countries such as Denmark and the US, restrictions on negotiating drug prices need to be removed. Up-to-date public information about DAA availability and pricing is also important [11]; such transparency shows governments that pharmaceutical companies are willing to negotiate a price that enables elimination. Since 1986, Management Sciences for Health and WHO have published the International Drug Price Indicator Guide, which lists drug prices from non-profit and procurement agencies - a valuable tool for tackling drug pricing [96].

\section{Public health approach in negotiations}

Drug price negotiations appear to be cyclical. Upon marketing approval, pharmaceutical companies often set high prices [97]; governments then enter negotiations with manufacturers, often with a fixed budget [40]. Reliable data on drug development and manufacturing costs would assist governments to negotiate reasonable prices [98] that take into account companies' justifiable need for profits. When drug development and manufacturing costs have been recovered, governments may have an easier time negotiating prices, enabling them (as in the case of DAAs) to quickly adopt a public health approach rather than an individual patient approach.

Pharmaceutical companies have shown preparedness to negotiate reasonable prices for DAAs, particularly when countries have comprehensive public health-based viral hepatitis elimination plans that facilitate treatment access for a large proportion of the affected population. Gilead has demonstrated its willingness to provide voluntary licenses that enable certain countries to access DAAs at a reduced price, as has GSK through the MPP.

Comprehensive viral hepatitis plans have centred on treatment as prevention and hepatitis $\mathrm{C}$ elimination 
rather than treating individual patients. These plans must be supported by reliable estimates of the number of people needing treatment so that governments can set elimination targets and monitor treatment outcomes. However, there are challenges in establishing hepatitis $\mathrm{C}$ surveillance systems (e.g. cost, establishing case definitions, laboratory infrastructure, training staff) [99], yet governments can learn from countries with surveillance systems in place (e.g. Australia, Egypt, Portugal).

\section{Conclusion}

History records very few opportunities to eliminate a chronic infection. In the DAA era, eliminating hepatitis $C$ as a public health threat is possible, yet it can only be achieved with affordable access to DAAs worldwide. Case studies of Australia, Portugal and Egypt demonstrate that comprehensive public health-based viral hepatitis plans facilitate negotiations with pharmaceutical companies. Shifting from individual-focused hepatitis $C$ treatment to elimination requires strong political will and advocacy. If price negotiations with pharmaceutical companies do not produce reasonable prices for DAAs, governments can utilise flexibilities in patent law to ensure access to low-priced generic sources.

\section{Abbreviations \\ ART: antiretroviral therapy; DAAs: direct-acting antivirals; FDA: Food and Drug Administration; GPRO: Global Procurement Fund; LDCs: least developed countries; MPP: Medicines Patent Pool; PBAC: Pharmaceutical Benefits Advisory Committee; PBS: Pharmaceutical Benefits Scheme; PWID: people who inject drugs; R\&D: research and development; TGA: Therapeutic Goods Administration; TRIPS: Trade-Related Aspects of Intellectual Property Rights; US: United States; WHO: World Health Organization; WTO: World Trade Organization}

\section{Acknowledgements}

The authors gratefully acknowledge Dr. Judy Gold and Dr. Campbell Aitken for their support with this manuscript.

\section{Funding}

The Burnet Institute receives support from the Victorian Government Operational Infrastructure Fund. Professor Margaret Hellard has received funding from Gilead Sciences, AbbVie and Bristol-Myers Squibb for investigator-initiated research. Dr. Alisa Pedrana has received funding from MSD for investigator-initiated research. Dr. Alisa Pedrana and Professor Margaret Hellard have received funding from NHMRC. JVL declares research grants from AbbVie, Gilead Sciences and MSD outside of this work. The funders had no role in this manuscript.

\section{Availability of data and materials}

Not applicable.

\section{Authors' contributions}

MEH developed the original plan for this debate piece. CD led the writing of the manuscript. All other authors contributed to writing the manuscript. All authors read and approved the final version prior to publication.

\section{Ethics approval and consent to participate}

Not applicable; no own data presented.

Consent for publication

Not applicable.

\section{Competing interests}

The authors declare that they have no competing interests.

\section{Publisher's Note}

Springer Nature remains neutral with regard to jurisdictional claims in published maps and institutional affiliations.

\section{Author details}

${ }^{1}$ Burnet Institute, Melbourne, Australia. ${ }^{2}$ Barcelona Institute for Global Health (ISGlobal), Hospital Clínic, University of Barcelona, Barcelona, Spain. ${ }^{3} \mathrm{CHIP}$, Rigshospitalet, University of Copenhagen, Copenhagen, Denmark. ${ }^{4} \mathrm{Global}$ Health Unit, University Medical Centre, Groningen, The Netherlands. ${ }^{5}$ Medicines Law and Policy, Amsterdam, The Netherlands. ${ }^{6}$ National Hepatology and Tropical Medicine Research Institute, Cairo, Egypt. ${ }^{7}$ Universidade Católica Portuguesa, Lisbon, Portugal. ${ }^{8}$ Faculty of Health, Medicine and Life Sciences, Maastricht University, Maastricht, The Netherlands. ${ }^{9}$ Department of Molecular and Clinical Pharmacology, Liverpool University, Liverpool, UK. ${ }^{10}$ Department of Infectious Diseases, The Alfred Hospital, Melbourne, Australia. ${ }^{11}$ Department of Epidemiology and Preventive Medicine, Monash University, Melbourne, Australia. ${ }^{12}$ Doherty Institute, University of Melbourne, Melbourne, Australia.

Received: 27 February 2018 Accepted: 29 August 2018

Published online: 09 October 2018

\section{References}

1. Centre for Disease Analysis Foundation. Polaris Observatory. 2018. http:// polarisobservatory.org/. Accessed 17 Jan 2018.

2. World Health Organization. Hepatitis C Fact Sheet. 2017. http://www.who. int/en/news-room/fact-sheets/detail/hepatitis-c. Accessed 11 Sept 2018.

3. Degenhardt L, Peacock A, Colledge S, Leung J, Grebely J, Vickerman P, Stone J, Cunningham EB, Trickey A, Dumchev K, Lynskey M, Griffiths P, Mattick RP, Hickman M, Larney S. Global prevalence of injecting drug use and sociodemographic characteristics and prevalence of HIV, HBV, and HCV in people who inject drugs: a multistage systematic review. Lancet Glob Health. 2017;5:e1192-207.

4. World Health Organization. Global health sector strategy on viral hepatitis 2016-2021. 2016. http://www.who.int/hepatitis/strategy2016-2021/ghss-hep/ en/. Accessed 13 Dec 2016.

5. Grebely J, Bruneau J, Bruggmann P, Harris M, Hickman M, Rhodes T, Treloar C. Elimination of hepatitis C virus infection among PWID: The beginning of a new era of interferon-free DAA therapy. Int J Drug Policy. 2017:47:26-33.

6. Scott N, Doyle JS, Wilson DP, Wade A, Howell J, Pedrana A, Thompson A, Hellard ME. Reaching hepatitis $C$ virus elimination targets requires health system interventions to enhance the care cascade. Int J Drug Policy. 2017;47:107-16.

7. Bajis S, Dore GJ, Hajarizadeh B, Cunningham EB, Maher L, Grebely J. Interventions to enhance testing, linkage to care and treatment uptake for hepatitis C virus infection among people who inject drugs: A systematic review. Int I Drug Policy. 2017:47:34-46.

8. Doyle JS, Thompson AJ, Higgs P, Stoove M, Dietze PM, Hellard ME. New hepatitis C antiviral treatments eliminate the virus. Lancet. 2017;390:358-9.

9. Rosenthal ES, Graham CS. Price and affordability of direct-acting antiviral regimens for hepatitis C virus in the United States. Infect Agent Cancer. 2016;11:24.

10. Hill A, Simmons B, Gotham D, Fortunak J. Rapid reductions in prices for generic sofosbuvir and daclatasvir to treat hepatitis C. J Virus Erad. 2016;2:28-31.

11. AndrieuX-Meyer I, Cohn J, ESA d A, Hamid SS. Disparity in market prices for hepatitis C virus direct-acting drugs. Lancet Glob Health. 2015;3:e676-7.

12. Iyengar S, Tay-Teo K, Vogler S, Beyer P, Wiktor S, de Joncheere K, Hill S. Prices, Costs, and Affordability of New Medicines for Hepatitis C in 30 Countries: An Economic Analysis. PLoS Med. 2016;13:e1002032.

13. JA DM, Grabowski HG, Hansen RW. Innovation in the pharmaceutical industry: New estimates of R\&D costs. J. Health Econ. 2016;47:20-33.

14. Morgan S, Grootendorst P, Lexchin J, Cunningham C, Greyson D. The cost of drug development: A systematic review. Health Policy. 2011;100:4-17.

15. Downing NS, Zhang AD, Ross JS. Regulatory Review of New Therapeutic Agents - FDA versus EMA, 2011-2015. N Engl J Med. 2017;376:1386-7.

16. Shah RR, Roberts $S A$, Shah DR. A fresh perspective on comparing the FDA and the CHMP/EMA: approval of antineoplastic tyrosine kinase inhibitors. $\mathrm{Br}$ J Clin Pharmacol. 2013;76:396-411.

17. Chary KV. Expedited drug review process: Fast, but flawed. J Pharmacol Pharmacother. 2016;7:57-61. 
18. Bhatia HK, Singh H, Grewal N, Natt NK. Sofosbuvir: A novel treatment option for chronic hepatitis C infection. J Pharmacol Pharmacother. 2014;5:278-84.

19. Panteli D, Arickx F, Cleemput I, Dedet G, Eckhardt H, Fogarty E, Gerkens S, Henschke C, Hislop J, Jommi C, Kaitelidou D, Kawalec P, Keskimäki I, Kroneman M, Lopez Bastida J, Pita Barros P, Ramsberg J, Schneider P, Spillane S, Vogler S, Vuorenkoski L, Wallach Kildemoes H, Wouters O, Busse R. Pharmaceutical regulation in 15 European countries: Review. In: Health Systems in Transition. Brussels: European Observatory on Health Systems and Policies; 2016.

20. Médecins Sans Frontières. Strategies to secure access to generic hepatitis C medicines. 2015. https://msfaccess.org/strategies-secure-access-generichepatitis-c-medicines. Accessed 11 Sept 2018.

21. Hill A. Access to Hepatitis Medicines. Sao Paulo: World Hepatitis Summit; 2017. http://www.worldhepatitissummit.org/docs/default-source/ presentations/strategic-direction-2/access-to-hepatitis-medicines-(andrewhill).pdf?sfvrsn=2. Accessed 10 Aug 2018.

22. Gilead. Gilead Sciences Announces Fourth Quarter and Full Year 2017 Financial Results. 2017. http://www.gilead.com/news/press-releases/2018/2/ gilead-sciences-announces-fourth-quarter-and-full-year-2017-financial-results. Accessed 13 Jun 2018.

23. Bristol-Myers Squibb. Bristol-Myers Squibb Reports Fourth Quarter and Full Year 2016 Financial Results. 2017. https://news.bms.com/press-release/ financial-news/bristol-myers-squibb-reports-fourth-quarter-and-full-year2016-financia. Accessed 21 Feb 2018.

24. Wirtz VJ, Hogerzeil HV, Gray AL, Bigdeli M, de Joncheere CP, Ewen MA Gyansa-Lutterodt M, Jing S, Luiza VL, Mbindyo RM, Möller H, Moucheraud C, Pécoul B, Rägo L, Rashidian A, Ross-Degnan D, Stephens PN, Teerawattananon Y, 't Hoen EFM, Wagner AK, Yadav P, Reich MR. Essential medicines for universal health coverage. Lancet. 2017:389:403-76.

25. Gvinjilia L. National progress toward Hepatitis C elimination-Georgia, 20152016. MMWR Morb Mortal Wkly Rep. 2016;65:1132-5.

26. Mitruka K, Tsertsvadze T, Butsashvili M, Gamkrelidze A, Sabelashvili P, Adamia E, Chokheli M, Drobeniuc J, Hagan L, Harris AM, Jiqia T, Kasradze A, Ko S, Qerashvili V, Sharvadze L, Tskhomelidze I, Kvaratskhelia V, Morgan J, Ward JW, Averhoff F. Launch of a Nationwide Hepatitis C Elimination Program-Georgia, April 2015. MMWR Morb Mortal Wkly. Rep. 2015;64:753-7.

27. Obach D, Yazdanpanah Y, Esmat G, Avihingsanon A, Dewedar S, Durier N, Attia A, Anwar WA, Cousien A, Tangkijvanich P, Eholie SP, Doss W, Mostafa A, Fontanet A, Mohamed MK, Deuffic-Burban S. How to optimize hepatitis C virus treatment impact on life years saved in resource-constrained countries. Hepatology. 2015;62:31-9.

28. Marshall AD, Cunningham EB, Nielsen $S$, Aghemo A, Alho H, Backmund M, Bruggmann P, Dalgard O, Seguin-Devaux C, Flisiak R, Foster GR, Gheorghe L, Goldberg D, Goulis I, Hickman M, Hoffmann P, Jancorienè L, Jarcuska P, Kåberg M, Kostrikis LG, Makara M, Maimets M, Marinho RT, Matičič M, Norris S, Ólafsson S, Øvrehus A, Pawlotsky J-M, Pocock J, Robaeys G, Roncero C, Simonova M, Sperl J, Tait M, Tolmane I, Tomaselli S, van der Valk M, Vince A, Dore GJ, Lazarus JV, Grebely J. Restrictions for reimbursement of interferonfree direct-acting antiviral drugs for HCV infection in Europe. Lancet Gastroenterol Hepatol. 2017:3:125-33.

29. van Santen DK, de Vos AS, Matser A, Willemse SB, Lindenburg K, MEE K, Prins M, de Wit GA. Cost-Effectiveness of Hepatitis C Treatment for People Who Inject Drugs and the Impact of the Type of Epidemic; Extrapolating from Amsterdam, the Netherlands. PLoS One. 2016:11:e0163488.

30. Martin NK, Vickerman P, Dore GJ, Grebely J, Miners A, Cairns J, Foster GR, Hutchinson SJ, Goldberg DJ, TCS M, Ramsay M, Hickman M. Prioritization of HCV treatment in the direct-acting antiviral era: An economic evaluation. J Hepatol. 2016;65:17-25

31. Norton BL, Fleming J, Bachhuber MA, Steinman M, DeLuca J, Cunningham CO, Johnson N, Laraque F, Litwin AH. High HCV cure rates for people who use drugs treated with direct acting antiviral therapy at an urban primary care clinic. Int J Drug Policy. 2017:47:196-201.

32. Yek C, de la Flor C, Marshall J, Zoellner C, Thompson G, Quirk L, Mayorga C, Turner BJ, Singal AG, Jain MK. Effectiveness of direct-acting antiviral therapy for hepatitis $C$ in difficult-to-treat patients in a safety-net health system: a retrospective cohort study. BMC Med. 2017;15:204.

33. Falade-Nwulia O, Suarez-Cuervo C, Nelson DR, Fried MW, Segal JB, Sulkowski MS. Oral direct-acting agent therapy for hepatitis $c$ virus infection: A systematic review. Ann Intern Med. 2017;166:637-48.

34. Martin NK, Vickerman P, Grebely J, Hellard M, Hutchinson SJ, Lima VD, Foster GR, Dillon JF, Goldberg DJ, Dore GJ, Hickman M. Hepatitis C virus treatment for prevention among people who inject drugs: Modeling treatment scale-up in the age of direct-acting antivirals. Hepatology. 2013; 58:1598-609.

35. Hellard M, Rolls DA, Sacks-Davis R, Robins G, Pattison P, Higgs P, Aitken C, McBryde $E$. The impact of injecting networks on hepatitis $C$ transmission and treatment in people who inject drugs. Hepatology. 2014;60:1861-70.

36. Trooskin SB, Reynolds H, Kostman JR. Access to Costly New Hepatitis C Drugs: Medicine, Money, and Advocacy. Clin Infect Dis. 2015;61:1825-30.

37. Brennan $\mathrm{H}$, Kapczynski A, Monahan $\mathrm{CH}$, Rizvi Z. A Prescription for Excessive Drug Pricing: Leveraging Government Patent Use for Health. Yale J Law Technol. 2016;18:7.

38. Barua S, Greenwald R, Grebely J, Dore GJ, Swan T, Taylor LE. Restrictions for medicaid reimbursement of sofosbuvir for the treatment of hepatitis $c$ virus infection in the United States. Ann Intern Med. 2015:163:215-23.

39. Kapadia SN, Jeng PJ, Schackman BR, Bao Y. State Medicaid Hepatitis C Treatment Eligibility Criteria and Use of Direct-Acting Antivirals. Clin Infect Dis. 2018;66:1618-20.

40. Ramani SV, Urias E. Access to critical medicines: When are compulsory licenses effective in price negotiations? Soc Sci Med. 2015;135:75-83.

41. World Trade Organization. Fact Sheet: TRIPS and pharmaceutical patents. 2006. https://www.wto.org/english/tratop_e/trips_e/factsheet_pharm02_e. htm. Accessed 21 Feb 2018.

42. Boldrin M, Levine DK. The case against patents. J Econ Perspect. 2013;27:3-22.

43. World Trade Organization. Extension of the transition period under article 66.1 of the TRIPS Agreement for Least Developed Country Members for certain obligations with respect to pharmaceutical products. Decision of the Council for TRIPS IP/C/73. Geneva: WTO; 2015.

44. Hill A, Swan T, Timmermans K. Technology and Market Landscape Hepatitis C Medicines. 2017. https://unitaid.eu/assets/HCV-Medicines-Landscape_Aug2017.pdf. Accessed 21 Feb 2018.

45. Mansfield SJ. Generic drug prices and policy in Australia: room for improvement? A comparative analysis with England. Aust Health Rev. 2014; 38:6-15.

46. Spinks J, Chen G, Donovan L. Does generic entry lower the prices paid for pharmaceuticals in Australia? A comparison before and after the introduction of the mandatory price-reduction policy. Aust Health Rev. 2013:37:675-81.

47. Médecins Sans Frontières. Untangling the web of antiretroviral price reductions. 2013.https://www.msf.org/sites/msf.org/files/msf_access_utw_ 16th_edition_2013.pdf. Accessed 22 Feb 2018.

48. World Trade Organization. Declaration on the TRIPS agreement and public health. 2001. https://www.wto.org/english/thewto_e/minist_e/min01_e/ mindecl_trips_e.htm. Accessed 21 Feb 2018.

49. World Trade Organization. WTO members welcome entry into force of amendment to ease access to medicines. 2017. https://www.wto.org/ english/news_e/news17_e/heal_30jan17_e.htm. Accessed 22 June 2018.

50. 't Hoen EFM, Veraldi J, Toebes B, Hogerzeil H. Medicine procurement and the use of flexibilities in the Agreement on Trade-Related Aspects of Intellectual Property Rights, 2001-2016. Bull World Health Organ. 2018;96(3):185-93.

51. 't Hoen EFM. Indian hepatitis $C$ drug patent decision shakes public health community. Lancet. 2016;387:2272-3.

52. Hill A. Treating Epidemic with Low-cost Generics. Australasian Viral Hepatitis Conference. Gold Coast; 2016. https://www.eiseverywhere.com/file_uploads/ 3e085e2ecc7ef5c0f3e5fe92e6bcf9f5_1430ThuAndrewHill_vMay.pdf. Accessed 10 Aug 2018

53. Juneja S, Gupta A, Moon S, Resch S. Projected savings through public health voluntary licences of HIV drugs negotiated by the Medicines Patent Pool (MPP). PLoS One. 2017;12:e0177770.

54. Gilead. Chronic Hepatitis C Treatment Expansion Generic Manufacturing for Developing Countries. 2015. https://www.gilead.com/ /media/files/pdfs/ other/hcv\%20generic\%20agreement\%20fast\%20facts\%2072815.pdf. Accessed 22 Feb 2018.

55. CLFB B, Bychkovsky BL, GdL L. Compulsory Licenses for Cancer Drugs: Does Circumventing Patent Rights Improve Access to Oncology Medications? J Glob Oncol. 2016:2:292-301.

56. Ghinea N, Lipworth W, Day R, Hill A, Dore GJ, Danta M. Importation of generic hepatitis $C$ therapies: bridging the gap between price and access in high-income countries. Lancet. 2017;389:1268-72.

57. Intellectual Property Watch. Malaysia Inclusion In Gilead Voluntary Licence A Product Of Compulsory Licence Pressure. 2017. www.ip-watch.org/2017/ 08/24/malaysia-inclusion-gilead-voluntary-licence-product-compulsorylicence-pressure/. Accessed 16 Feb 2018. 
58. Medicines Patent Pool. License and technology transfer agreement. 2015. https://medicinespatentpool.org/uploads/2015/11/MPP-HCV-LicenseAgreement-BMS-FINAL-Web-00000002.pdf. Accessed 22 Jun 2018.

59. White S, Irani S. How does patent opposition in Australia compare with opposition in Europe? Intellectual Property Forum. 2015;102:56-63.

60. Médecins Sans Frontières. MSF joins Europe-wide action challenging patent on key hepatitis C drug. 2017. https://msf.lu/en/news/press-releases/msfjoins-europe-wide-action-challenging-patent-on-key-hepatitis-c-drug. Accessed 21 Feb 2018

61. Silverman E. European regulator amends some Gilead hep C patent claims. 2016. https://www.statnews.com/pharmalot/2016/10/05/gilead-sovalideurope-invalidated/. Accessed 21 Feb 2018.

62. Médecins Sans Frontières. Patent Opposition Database: About. 2018. https:// www.patentoppositions.org/en/about. Accessed 17 Jan 2018.

63. Conti RM, Gee RE, Sharfstein JM. Pharmaceuticals and public health. JAMA 2016;316:2083-4

64. European Commission. European Commission Green Public Procurement (GPP) Training Toolkit. 2008. http://ec.europa.eu/environment/gpp/pdf/ toolkit/module1_factsheet_joint_procurement.pdf. Accessed 26 Feb 2018.

65. Pan American Health Organization. MERCOSUR countries create a negotiating mechanism to procure high-cost medicines, with $\mathrm{PAHO}$ support. 2015. http://www.paho.org/hq/index.php?option=com_ content\&view=article\&id=11441\%3A2015-mercosur-estados-asociadosconcretaron-mecanismo-de-compra-de-medicamentos-de-alto-costo-conapoyo-ops\&ltemid=1926\&lang=en6. Accessed 21 Feb 2018.

66. Brennan Z. South American Health Ministers Negotiate Lower Prices for Antivirals and Antiretrovirals. 2015. http://www.raps.org/Regulatory-Focus/ News/2015/11/20/23652/South-American-Health-Ministers-Negotiate-LowerPrices-for-Antivirals-Antiretrovirals/. Accessed 21 Feb 2018.

67. Global Procurement Fund. Intro. 2017. http://cdafound.org/gpro/. Accessed 11 Sept 2018.

68. Global Procurement Fund. GPRO FAQ. 2017. http://cdafound.org/gpro_faq/. Accessed 11 Sept 2018.

69. Therapeutic Goods Administration. Personal importation scheme. 2015. https:// www.tga.gov.au/personal-importation-scheme. Accessed 21 Feb 2018.

70. 't Hoen EFM. The Italian Exception - A personalised approach to accessing high-priced patented medicines. 2017. https://medicineslawandpolicy.org/ 2017/05/the-italian-exception-a-personalised-approach-to-access-to-highpriced-patented-medicines/. Accessed 16 Feb 2018.

71. Swissmedic. Guideline on medicines and the Internet.2017. https://www swissmedic.ch/swissmedic/en/home/humanarzneimittel/marketsurveillance/medicinal-products-from-the-internet/leitfaden-arzneimittel-ausdem-internet.html. Accessed 22 Feb 2018

72. FixHepC. Order. 2017. https://fixhepc.com/order.html. Accessed 21 Feb 2018.

73. Freeman J, Sallie R, Kennedy A, PTN H, Freeman J, Jeffreys G, Hill AM. High Sustained Virological Response Rates Using Generic Direct Acting Antiviral Treatment for Hepatitis C, Imported into Australia. J Hepatol. 2016;64:S209.

74. Vitry Al, Thai L, Roughead EE. In: Zud B, editor. Pharmaceutical Pricing Policies in Australia. In Pharmaceutical Prices in the 21st Century. Basel: Springer International Publishing; 2015. p. 1-23.

75. Grove A. The Pharmaceutical Benefits Scheme: a quick quide. 2016. https://www. aph.gov.au/About_Parliament/Parliamentary_Departments/Parliamentary_Library/ pubs/rp/rp1516/Quick_Guides/PBS. Accessed 22 Feb 2018

76. Department of Health Australia. Pharmaceutical Benefits Fees, Patient Contributions and Safety Net Thresholds. 2018. http://www.pbs.gov.au/info/ healthpro/explanatory-notes/front/fee. Accessed 21 Feb 2018.

77. Hellard $\mathrm{M}$, Thompson AJ. Inaccurate reporting creates further stigma for hep C patients. 2016. https://www.burnet.edu.au/news/777_inaccurate_reporting_ creates_further_stigma_for_hep_c_patients. Accessed 21 Feb 2018.

78. The Kirby Institute. Monitoring hepatitis $C$ treatment uptake in Australia. 2017. https://kirby.unsw.edu.au/sites/default/files/kirby/report/Monitoringhep-C-treatment-uptake-in-Australia_Iss8-DEC17.pdf. Accessed 22 Feb 2018.

79. Department of Health Australia. General Statement for Drugs for the Treatment of Hepatitis C. 2017. http://www.pbs.gov.au/info/healthpro/ explanatory-notes/general-statement-hep-c. Accessed 21 Feb 2018.

80. Baptista Leite R. Hepatitis C: Policy in Action. Brussels: European Public Health Alliance; 2017. https://epha.org/wp-content/uploads/2017/03/9. Ricardo-Baptista-Leite-Lets_END_HEP_C_FINAL_22032017.pdf. Accessed 10 Aug 2018

81. Tato-Marinho R, Mota-Filipe H, Martins AP, Martins J, Rodrigues J, Andreozzi V, Vandewalle B, Félix J, Alves EC. Universal Access to New Generation
Direct-Acting Antivirals to Reduce the Burden of Hepatitis C in Portugal. J. Hepatol. 2017:64:5816-7.

82. Infarmed. Infarmed approved 34 treatment applications of patients with Hepatitis C genotype 2. 2017. http://www.infarmed.pt/documents/15786/ 1879176/Nota+de+Imprensa+-+Infarmed+aprovou+34+pedidos+de +tratamento++de+doentes+com+gen\%C3\%B3tipo+2+da+Hepatite+C/ 6588bd7b-6013-4716-beb0-cb206437070f. Accessed 28 Feb 2018

83. Martins J, Rodrigues J, Martins AP, Andreozzi V, Vandewalle B, Félix J, Alves EC, Mota-Filipe H. Long-Term Effect of the Portuguese Universal Access Program to New Generation Direct-Acting Antivirals for the Treatment of Hepatitis C. J Hepatol. 2016:64:S778-9.

84. The Boston Consulting Group. Road to Elimination: Barriers and Best Practices in Hepatitis C Management: Overview of the status of HCV care in Europe and Australia. 2017. http://image-src.bcg.com/Images/BCG-Road-toElimination_tcm104-166034.pdf. Accessed 22 Feb 2018.

85. Elgharably A, Gomaa Al, MME C, Norsworthy PJ, Waked I, Taylor-Robinson SD. Hepatitis C in Egypt - past, present, and future. Int J Gen Med. 2017;10:1-6.

86. Guerra J, Garenne M, Mohamed MK, Fontanet A. HCV burden of infection in Egypt: results from a nationwide survey. J Viral Hepat. 2012;19:560-7.

87. Ministry of Health and Population Cairo, El Zanaty and Associates, ICF International. Egypt Health Issues Survey 2015. 2015. https://dhsprogram. com/pubs/pdf/FR313/FR313.pdf. Accessed 22 Feb 2018.

88. Dore GJ, Ward J, Thursz M. Hepatitis C disease burden and strategies to manage the burden. J Viral Hepat. 2014;21(Suppl 1):1-4

89. Kandeel A, Genedy M, El-Refai S, Funk AL, Fontanet A, Talaat M. The prevalence of hepatitis C virus infection in Egypt 2015: implications for future policy on prevention and treatment. Liver Int. 2017;37:45-53.

90. Gomaa A, Allam N, Elsharkway A, El Kassas M, Waked I. Hepatitis C infection in Egypt: prevalence, impact and management strategies. Hepat. Med. 2017;9:17-25.

91. Elsharkawy A, Raziky ME, Akel WE, Saeed KE, Eletreby R, Hassany M, El-Sayed MH, Kabil K, Ismail SA, El-Serafy M, Abdelaziz AO, Shaker MK, Yosry A, Doss W, Shazly YE, Esmat G, Waked I. Planning and prioritizing direct acting antivirals treatment for HCV patients in countries with limited resources: lessons from the Egyptian experience. J Hepatol. 2018;68(4):691-8.

92. Médecins Sans Frontières. Not even close. 2017. https:/www.msf.org/sites/ msf.org/files/hepc_issuebrief_hep_c_2017.pdf. Accessed 22 Feb 2018.

93. Medicines Patent Pool. MedsPal Egypt. 2018. http://www.medspal.org/ ?country_name=Egypt. Accessed 21 Feb 2018.

94. World Health Organization. Global hepatitis report. 2017. http://apps.who.int/iris/ bitstream/10665/255016/1/9789241565455-eng.pdf?ua=1. Accessed 21 Feb 2018.

95. Hellard M, Pedrana A, Scott N. Targeted direct-acting antiviral treatment for chronic hepatitis C: A financial reality or an obstacle to elimination? J Hepatol. 2017;66:270-2.

96. Management Sciences for Health. International Drug Price Indicator Guide, 2014. 2015. http://apps.who.int/medicinedocs/documents/s21982en/ s21982en.pdf. Accessed 22 Feb 2018

97. Deangelis CD. Big Pharma Profits and the Public Loses. Milbank Q. 2016;94:30-3.

98. Hill A, Khoo S, Fortunak J, Simmons B, Ford N. Minimum Costs for Producing Hepatitis C Direct-Acting Antivirals for Use in Large-Scale Treatment Access Programs in Developing Countries. Clin Infect Dis. 2014;58:928-36.

99. Jafari N, Farajzadegan Z, Ataei B. Surveillance system for hepatitis C infection: A practical approach. Int J Prev Med. 2012;3:S48-57.

Ready to submit your research? Choose BMC and benefit from:

- fast, convenient online submission

- thorough peer review by experienced researchers in your field

- rapid publication on acceptance

- support for research data, including large and complex data types

- gold Open Access which fosters wider collaboration and increased citations

- maximum visibility for your research: over $100 \mathrm{M}$ website views per year

At BMC, research is always in progress.

Learn more biomedcentral.com/submissions 